\title{
PENGAYAAN PENGETAHUAN DAN PRAKTEK PEMANFAATAN SUPLEMEN BERBASIS PAKAN LOKAL UNTUK KAMBING PADA KELOMPOK PETERNAK DI DESA BAUMATA UTARA
}

\author{
E.D. Wie Lawa, M.F. Lalus dan E.J.L.Lazarus \\ Fakultas Peternakan UNDANA, Kupang \\ E-mail koresponden : emmawielawa@gmail.com
}

\begin{abstract}
ABSTRAK
Program kemitraan masyarakat (PKM) berupa teknologi penyediaan pakan suplemen berbasis pakan lokal telah dilaksanakan di desa Baumata Utara, Kecamatan Taebenu, Kabupaten Kupang. Sebanyak 24 orang peserta peternak kambing ikut serta dalam kegiatan ini. Kegiatan yang dilakukan adalah kegiatan penyuluhan untuk memperkaya pengetahuan peternak terhadap penyediaan pakan untuk ternak kambing. Pemaparan materi dan diskusi seputar pemeliharaan kambing, jenis pakan dan cara menyajikannya merupakan metode yang dilakukan dalam kegiatan ini. Kegiatan pelatihan dilakukan dalam bentuk praktek penyusunan ransum menggunakan bahan pakan lokal yang dapat memenuhi kebutuhan bagi pertumbuhan kambing. Dalam kegiatan pelatihan ditunjukkan berbagai bahan pakan konsentrat yang dapat digunakan dalam ransum sebagai suplemen dan pakan lokal yang berasal dari hijauan leguminosa yang telah diproses menjadi tepung. Pencampuran bahan pakan disesuaikan dengan kebutuhan kambing dan dapat diikuti peserta dengan baik. Kegiatan dilanjutkan dengan memberikan pakan yang telah diramu kepada kambing yang ada. Masyarakat mitra peserta kegiatan PKM mendapat pengayaan dan ketrampilan penyediaan pakan bagi ternak kambing yang dipelihara dengan mengandalkan pakan lokal yang terdapat di sekitar usaha peternakannya serta dapat mengadopsi informasi teknologi penyediaan pakan untuk ternak kambing.
\end{abstract}

Kata Kunci : Pakan lokal, konsentrat, penyuluhan, pelatihan, pemberdayaan 


\section{PENDAHULUAN}

Ternak kambing dipelihara masyarakat dengan tujuan meningkatkan pendapatan mereka dan sebagai basis ekonomi yang sangat menjanjikan jika sistem pemeliharaan dilaksanakan dengan baik. Peranan ternak kambing sebagai penyumbang pendapatan (income generating) dan penyumbang sumber protein ternak sangat mendukung program penyediaan daging nasional (Soedjana, 1993). Peranan ternak kambing yang penting ini perlu didukung melalui penyediaan lingkungan yang sesuai bagi pertumbuhan kambing, seperti dikemukakan Coffey et al. (2004) bahwa melalui intergrasi peternakan ke dalam sistem pertanian dapat meningkatkan kesehatan lingkungan dan ekonomi serta keberagaman, di samping sebagai penyumbang utama terhadap keberlanjutan pertanian.

Pakan merupakan salah satu faktor yang sangat penting dalam usaha ternak kambing bahkan dapat dikatakan bahwa keberhasilan suatu usaha peternakan tergantung pada manajemen pakan. Permasalahan yang umumnya dihadapi masyarakat peternak di desa Baumata Utara ini adalah penyediaan pakan berkualitas yang secara kontinyu mencukupi kebutuhan ternak belum terpenuhi. Kondisi ini akan lebih terasa ketika musim kemarau. Hasil wawancara dengan masyarakat peternak diperoleh informasi bahwa hal utama dalam penyediaan pakan adalah sulitnya mencari pakan setiap hari bagi ternak mereka. Keadaan ini lebih sulit lagi karena peternak lebih mengandalkan rumput sebagai pakan utama bagi kambing yang dipeliharanya. Rumput alam sebagai pakan utama kambing pada musim kemarau kualitas dan kuantitasnya menurun secara drastis sehingga sangat mempengaruhi pertumbuhan. Pengetahuan yang minim mengenai pakan kambing menjadi faktor utama dalam masalah ini. Ketersediaan hijauan pakan selain rumput di sekitar usaha peternakan kambing berpotensi dalam menyediakan pakan yang kontinyu dan tentunya berkualitas untuk kambing yang dipelihara. Pakan hijauan yang berbasis lokal seperti hijauan leguminosa dan non leguminosa banyak tersedia di pekarangan rumah, ladang, kebun dan hutan dapat dimanfaatkan sebagai pakan kambing namun belum dimanfaatkan dengan maksimal akibat kurangnya informasi yang diperoleh masyarakat.

Selain minimnya informasi yang diketahui tentang jenis pakan untuk kambing, sistem pemeliharaan khususnya cara penyediaan pakan yang berkualitas dan ekonomis bagi kambing masih kurang dipahami. Pakan penguat sebagai suplemen dalam ransum kambing dapat meningkatkan dan mempercepat pertumbuhan. Penambahan pakan ini dalam jumlah terbatas pada ransum akan meningkatkan efisiensi pemeliharaan dari ternak yang dipelihara. Pakan 
penguat (konsentrat) seperti jagung, dedak padi, umbi-umbian, isi batang gewang (putak) dapat dimanfaatkan sebagai sumber karbohidrat sementara tepung ikan, bungkil kelapa dan berbagai daun leguminosa dapat dimanfaatkan sebagai sumber protein untuk memenuhi kebutuhan kambing. Pakan penguat atau konsentrat ini mengandung nutrisi tinggi dengan kadar serat kasar yang rendah (Akoso, 1998).

Berdasarkan hal tersebut di atas maka telah dilakukan kegiatan kemitraan dengan masyarakat (PKM) dengan tujuan meningkatkan pengetahuan dan ketrampilan masyarakat dalam beternak kambing khususnya dalam penyediaan pakan yang berbasis pada pakan lokal yang ada di sekitar usaha peternakan kambing dilakukan.

\section{METODE PELAKSANAAN}

Kegiatan yang dilakukan dalam Program Kemitraan Masyarakat (PKM) ini meliputi kegiatan penyuluhan dan pelatihan pemanfaatan pakan lokal untuk kambing bagi masyarakat mitra di desa Baumata Utara, kecamatan Taebenu, Kabupaten Kupang, Nusa Tenggara Timur. Sebanyak 24 orang peserta mitra mengikuti kegiatan ini dengan narasumber 3 orang. Kegiatan penyuluhan bertujuan memperkaya pengetahuan masyarakat peternak kambing dalam pemeliharaan kambing secara umum dan khususnya berbagai jenis pakan dan cara pemberiannya dalam ransum kambing. Dalam penyuluhan masyarakat mitra peserta disuguhi informasi tentang jenis-jenis pakan untuk kambing dan cara pemberian pakan untuk kambing. Sistem pemaparan materi dan dilanjutkan dengan diskusi diterapkan dalam kegiatan ini. Masyarakat peserta dibekali dengan informasi tertulis sebagai pegangan untuk mengikuti penyuluhan dan untuk memberikan kesempatan merespon atas materi penyuluhan sehingga ada timbal balik dalam diskusi yang dilakukan. Masyarakat peserta dirangsang untuk menyampaikan informasi yang diketahuinya tentang jenis tanaman yang ada dan dikenal dalam kehidupannya sehari-hari yang berpotensi digunakan sebagai pakan kambing.

Kegiatan pelatihan pemanfaatan pakan lokal untuk kambing dilakukan setelah selesai kegiatan penyuluhan. Materi pelatihan berupa bahan pakan penguat (konsentrat) yaitu, jagung giling, dedak padi, bungkil kelapa, bungkil kedelai, tepung putak, tepung daun lamtoro, tepung daun gamal dan tepung daun kabesak putih ditunjukkan sebagai contoh yang dapat digunakan dalam ransum kambing. Jagung giling dan dedak padi serta bungkil kelapa merupakan konsentrat yang dapat diperoleh dengan mudah dan pemanfaatannya dalam 
ransum tidak dalam jumlah yang besar, demikian juga dengan bungkil kelapa dengan mudah diperoleh dari masyarakat yang memproduksi minyak kelapa. Tepung putak diperoleh dari proses penggilingan gelondongan batang gewang. Tepung daun lamtoro, daun gamal dan daun kabesak putih diperoleh dengan cara sebagai berikut :

1. Daun lamtoro, gamal dan kabesak putih dipanen dari tanaman yang sehat

2. Daun yang telah dipanen dikeringkan dengan cara diangin-anginkan selama 7 hari

3. Daun yag telah kering digiling menjadi tepung dan dimasukkan dalam karung plastik

4. Simpan dalam ruangan sampai waktu digunakan

Menurut Suprayitno (1981), daun lamtoro dapat digunakan sebagai bahan baku makanan ternak, baik yang diberikan secara langsung yaitu sebagai hijauan segar, maupun melalui proses penepungan, tablet atau pellet. Tanaman lamtoro diketahui banyak mengandung protein dan sangat baik digunakan sebagai pakan ternak. Palatabilitas tanaman ini sangat tinggi, pertumbuhan cepat dan mudah tumbuh di daerah tropis. Lamtoro mengandung PK 23,7\%, SK 18\%, LK 5,8\% (Hartadi, $d k k ., 2005$ ). Demikian juga daun gamal mengandung nutrisi yang tinggi, dimana kandungan PK 25,17\%, SK 19,89\% dan LK 2,90\% (Wina dan Syahgiar, 1991). Daun kabesak putih yang merupakan tanaman lokal endemik di pulau Timor mengandung PK 14,7\%, SK 30,4\% dan LK 0,07\% (Lawa, et al., 2017). Tanaman-tanaman tersebut merupakan contoh tanaman lokal yang dapat dimanfaatkan oleh masyarakat sebagai pakan kambing. Sri Wigati $d k k$. (2016) menyatakan dari hasil kegiatan IbM, hijauan pakan dalam bentuk kering lebih mudah diterima ternak kambing dan pemberiannya dapat mencapai 30-100\% dari kebutuhan hijauan pada ternak.

Peralatan yang disiapkan dalam pelatihan antara lain baskom, timbangan, peralatan pendukung lainnya untuk pencampuran ransum. Ransum yang disusun disesuaikan dengan berat badan kambing dan status kehidupan kambing. Dalam kegiatan ini disusun untuk kambing yang sedang bertumbuh dengan berat badan sekitar 15 kilogram. Kebutuhan BK $2,5 \%$ dari $\mathrm{BB}=2,5 \% \times 15 \mathrm{~kg}=375$ gram per ekor per hari. Bahan pakan disusun sesuai kebutuhan kambing akan PK $=12 \%$ dan TDN (energi) $=61 \%$. Semua bahan disusun sesuai takaran untuk memenuhi kebutuhan kambing tersebut. Hasil penimbangan kemudian dimasukkan dalam wadah yang sesuai digunakan masyarakat (kaleng susu) sehingga lebih mudah diterapkan. Setelah pencampuran bahan pakan khususnya konsentrat, dilanjutkan dengan pemberian pada kambing. Hijauan pakan tetap diberikan sebagai pakan basal dapat berupa rumput maupun dedaunan yang ada. Komposisi penyusun dari bahan-bahan tersebut 
seperti tercantum dalam Tabel 1, dimana dicontohkan ransum yang mengandung tepung daun kabesak putih.

Tabel 1. Susunan bahan penyusun ransum kambing

$\begin{array}{ll}\text { Bahan pakan } & \text { Porsi dalam ransum } \\ \text { Bungkil kedelai } & 3,0 \\ \text { Bungkil kelapa } & 5,0 \\ \text { Dedak padi } & 7,0 \\ \text { Jagung giling } & 5,0 \\ \text { Tepung daun kabesak putih } & 20,0 \\ \text { Rumput } & 60,0\end{array}$

\section{HASIL DAN PEMBAHASAN}

Kegiatan penyuluhan diikuti dengan serius oleh masyarakat peserta serta adanya upaya peserta untuk mau memahami apa yang disampaikan. Masyarakat mitra peserta kegiatan diajak untuk dapat memperbaiki kehidupannya melalui pemberdayaan potensi diri. Menurut Syufri (2005), dalam pembangunan pertanian dibutuhkan suatu kegiatan pemberdayaan agar masyarakat petani dapat menjadi manusia seutuhnya dan menjadi subjek dari pembangunan itu sendiri. Pemeliharaan ternak kambing dengan mengandalkan potensi pakan lokal yang ada di sekitar kehidupannya merupakan upaya pemberdayaan dalam rangka meningkatkan kesejahteraan dengan memanfaatkan semua sumberdaya yang dimiliki dan yang ada di sekitarnya. Hal ini seperti dikemukakan Setiana (2005) bahwa, kegiatan pemberdayaan masyarakat adalah upaya mengaktualisasikan potensi yang sudah dimiliki sendiri oleh masyarakat. Masyarakat mitra dikenalkan pada berbagai tanaman lokal yang berpotensi sebagai pakan ternak kambing. Keberadaan tanaman-tanaman tersebut telah dikenal masyarakat, baik yang ada di pekarangan rumah, kebun, ladang maupun yang ada di hutan namun belum dimanfaatkan dengan baik sebagai pakan kambing.Tanaman-tanaman tersebut memiliki kandungan nutrisi yang baik untuk dimanfaatkan sebagai pakan. Dalam penjelasan kepada mitra masyarakat peternak, mereka menjadi mengetahui, mengerti dan memahami bahwa pakan untuk ternak kambing dapat diperoleh di sekitar usaha pertanian yang mereka lakukan sehari-hari. Melalui pengetahuan dan pemahaman yang dimiliki, masyarakat diharapkan menjadi mandiri dan meningkat kemampuannya dalam pemeliharaan ternak 
kambing dengan memanfaatkan segala sumberdaya yang dimiliki untuk meningkatkan kesejahteraannya.

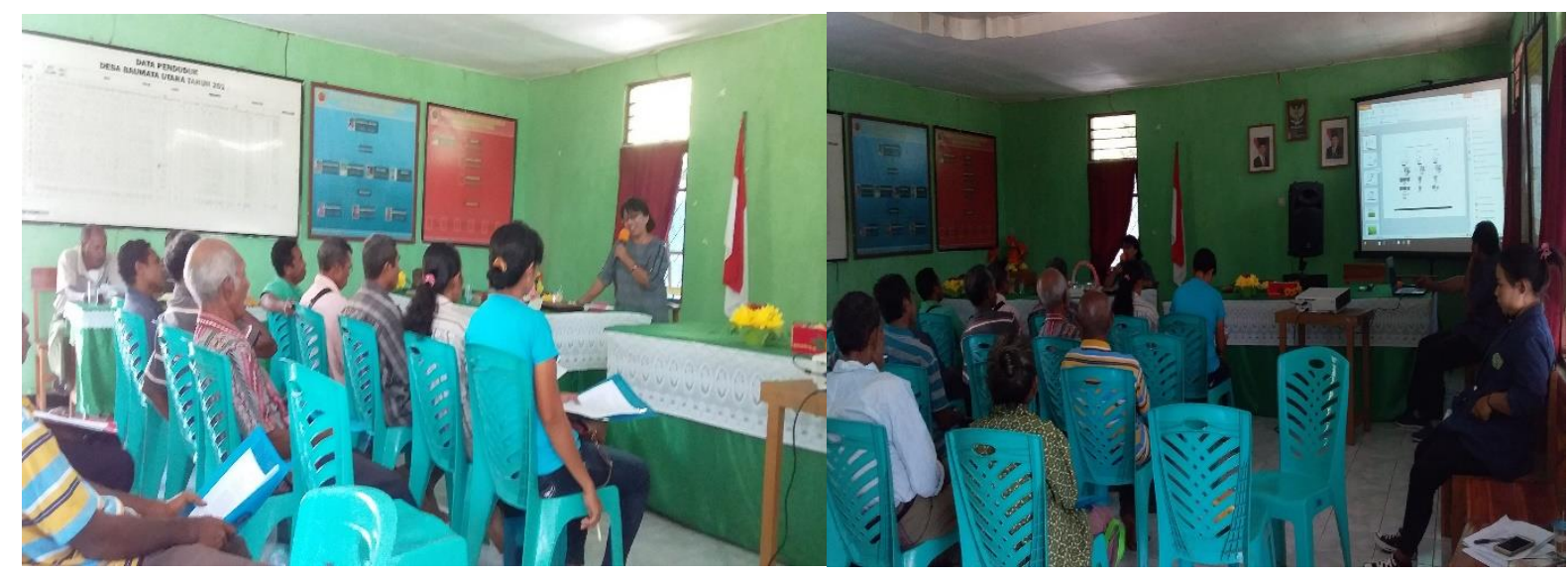

Gambar 1. Suasana kegiatan penyuluhan tentang pakan kambing

Kegiatan pelatihan bertujuan memberikan nuansa aplikasi terhadap teknologi penyediaan pakan yang bermanfaat bagi masyarakat. Penyediaan pakan hijauan untuk ternak kambing dan ternak ruminansia lainnya selalu menjadi masalah terutama di musim kemarau dimana hijauan jenis rumput dan leguminosa sulit didapat (Kushartono dan Iriani, 2004). Leguminosa sebagai pakan ternak mempunyai susunan zat makanan yang sangat baik, selain itu daunnya sangat disukai ternak kambing. Hasil penelitian Wina (1992) menunjukkan bahwa penggunaan daun leguminosa sebagai ransum domba menghasilkan pertambahan berat badan yang baik. Pakan untuk kambing harus disusun secara terencana dan komposisinya harus berimbang dengan takaran yang tepat untuk setiap komponen nutrisi seperti protein, karbohidrat, lemak, mineral dan vitamin dan juga disesuaikan dengan umur dan sasaran kepentingan pemeliharaan (Akoso, 1998). Tidak cukupnya nutrisi bagi ternak kambing berkaitan dengan kehilangan ekonomi yang besar bagi peternak karena ternak mengalami kehilangan berat, menurunnya kapasitas reproduksi dan meningkatnya tingkat kematian. 


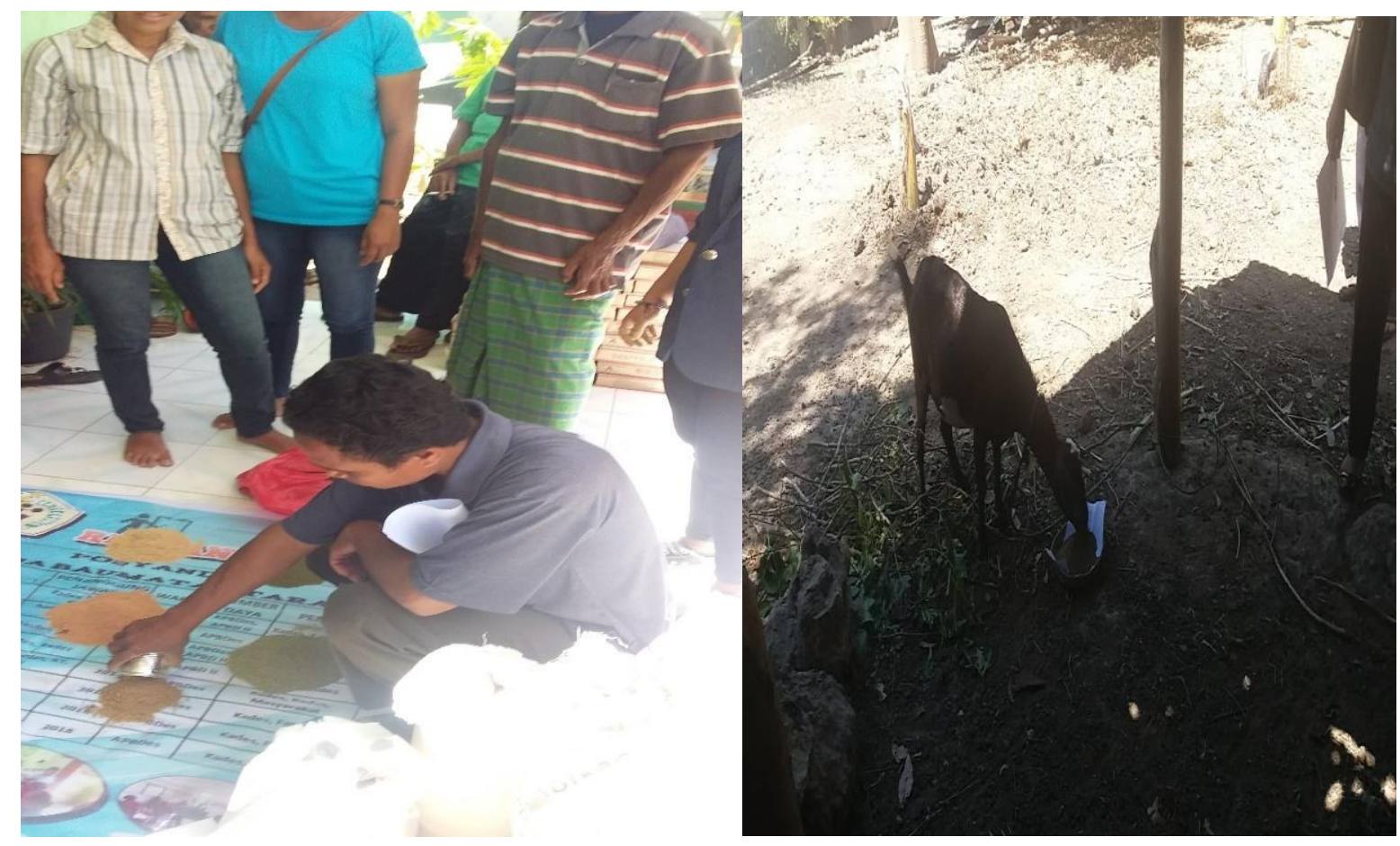

Gambar 2. Praktek penyusunan ransum dan pemberian pada ternak kambing

Peserta pelatihan diberikan pemahaman bahwa untuk mendapatkan pertumbuhan kambing yang baik maka perbaikan dalam penyediaan pakan mutlak dilakukan. Hasil penelitian Nuraini, $d k k$. (2014) menyimpulkan bahwa, perbaikan pakan dengan pemberian pakan penguat dapat meningkatkan pertumbuhan kambing Bligon. Demikian juga Kushartono dan Iriani (2004) menyatakan bahwa dengan semakin banyaknya keanekaragaman pakan, baik kelompok rumput, leguminosa dan hijauan lain serta limbah pertanian diharapkan dapat meningkatkan daya dukung penyediaan pakan ruminansia dan pada akhirnya dapat meningkatkan pendapatan peternak. Penggunaan pakan lokal dalam bentuk konsentrat dalam ransum kambing akan meningkatkan efisiensi dalam pemeliharaan. Menurut Traiyakun et al. (2011), sumber protein lokal dari hijauan semak dan pohon dapat digunakan untuk menggantikan protein pakan import seperti bungkil kedelai. Bahkan Lawa et al. (2017) dari hasil penelitiannya menyatakan bahwa terdapat peningkatan konsumsi, kecernaan dan pertumbuhan kambing yang mendapat tepung daun kabesak putih sebagai pengganti bungkil kedelai dalam konsentrat yang digunakan sebagai suplemen. Penggantian bungkil kedelai sebesar $20 \%$ menghasilkan pertumbuhan kambing terbaik.

Hasil penyuluhan dan pelatihan dalam kegiatan program kemitraan masyarakat (PKM) ini diharapkan masyarakat termotivasi dan dapat mengadopsi informasi dan menerapkannya 
dalam usaha peternakan kambing yang dilakukannya. Menurut Mardikanto (1993), adopsi dapat diartikan sebagai proses perubahan perilaku, baik yang berupa pengetahuan (cognitive), sikap (affective), maupun ketrampilan (psychomotoric) pada diri seseorang setelah menerima inovasi yang disampaikan. Inovasi sendiri adalah suatu ide, perilaku, produk, informasi dan praktek-praktek baru yang belum banyak diketahui, diterima dan digunakan/diterapkan/dilaksanakan oleh sebagian besar warga masyarakat dalam suatu lokalitas tertentu, yang dapat digunakan atau mendorong terjadinya perubahan-perubahan di masyarakat.

\section{KESIMPULAN}

Masyarakat mitra peserta kegiatan PKM mendapat pengayaan dan ketrampilan penyediaan pakan bagi ternak kambing yang dipelihara dengan mengandalkan pakan lokal yang terdapat di sekitar usaha peternakannya serta dapat mengadopsi informasi teknologi penyediaan pakan untuk ternak kambing.

\section{UCAPAN TERIMA KASIH}

Ucapan terima kasih disampaikan kepada Universitas Nusa Cendana melalui Lambaga Penelitian dan Pengabdian pada Masyarakat (LPPM) yang telah mendanai kegiatan PKM ini dengan surat perjanjian pelaksanaan No. 62/UN15.19/PM/2018 Tanggal 7 Mei 2018.

\section{DAFTAR PUSTAKA}

Akoso, B.T. 1998. Kesehatan Sapi. Kanisius, Yogyakarta.

Coffey, L., H. Margo and A. Wells. 2004. Goats: Sustainable Production Overview. Livestock Production Guide. National Sustainable Agriculture Information Service (ATTRA)., Butte, Montana and Davis., California.

Hartadi, H., S. Reksohadiprodjo dan A.D. Tillman. 2005. Tabel Komposisi Pakan untuk Indonesia. Gadjah Mada University Press, Yogyakarta. 
Kushartono, B. dan N. Iriani. 2004. Inventarisasi keanekaragaman pakan hijauan guna mendukung sumber pakan ruminansia. Proseding Temu Teknis Nasional Tenaga Fungsional Pertanian, Jakarta.

Lawa, E.D.W., Marjuki., Hartutik and S. Chuzaemi. 2017. Effect of white kabesak (Acacia leucophloea Roxb) leaves level in the diet on feed intake and body weight gain of Kacang goat. Journal of The Indonesian Tropical Animal Agriculture (JITAA). Vol. $42(4), 255-262$.

Mardikanto, T. 1993. Penyuluhan Pembangunan Pertanian. Sebelas Maret University Press, Surakarta.

Nuraini., I G.S. Budisatria dan Ali Agus. 2014.Pengaruh tingkat penggunaan pakan penguat terhadap performa induk kambing Bligon di peternakan rakyat. Buletin Peternakan. Vol. 38 (1), 34-41.

Setiana, L. 2005. Teknik Penyuluhan dan Pemberdayaan Masyarakat. Ghalia Indonesia, Bogor.

Soedjana, T.J. 1993. Aspek Ekonomi Beternak Ruminansia Kecil (Economics of Raising Small Ruminants). UNS Press. Pp. 336-368.

Sri Wigati., E. Wiyanto dan Maksudi. 2016. IbM kelompok tani kambing rakyat untuk introduksi teknologi dan strategi pembentukan sistem lumbung pakan ternak. Jurnal Pengabdian pada Masyarakat, Universitas Jambi. Vol. 31 (2), 20-24.

Suprayitno. 1981. Lamtoro Gung dan Manfaatnya. Bharatara, Jakarta

Syufri, A. 2005. Memberdayakan sumberdaya manusia petani-nelayan. http://www.sumber.litbang.deptan.go.id/hln26122055_as.htm.

Traiyakun, S., W. Harakord., C. Yuangklang and P. Paengkoum. 2011. Leucaena leucocephala meal as replacement to soybean meal in growing goat diets. J. Agric. Sci. Technol. A. 1, 1150-1154.

Wina, E. dan S. Syahgiar. 1991. Gamal (Gliricidia sepium) dan Manfaatnya. BPT Bogor. Wina, E. 1992. Nilai gizi kaliandra, gliricidia dan lamtoro sebagai suplemen untuk domba yang diberi rumput gajah. Proseding Pengolahan dan Komunikasi Hasil-hasil 
Pertanian. Balai Penelitian Ternak. Pusat Penelitian dan Pengembangan Peternakan.

Hal. 13-19. 